\title{
Mad rant or "taking the piss?": A case study of when attempts at humour go wrong
}

\author{
Bronwyn McGovern \\ University of Otago, New Zealand \\ bronwyn.mcgovern@otago.ac.nz
}

\begin{abstract}
In 2010, Brother a well-known local identity living on a busy street corner in Wellington, told court appointed psychiatrists he boogied with the dead and was enjoying life in 1984. Though academic writing on the homeless experience unanimously proposes that street life existence is essentially 'no laughing matter', and while Brother's talk could be dismissed as the ramblings of a mad man, here I argue that his banter can be understood as displaying an acute sense of underdog humour (Coser 1959). Drawing from participant observational research spanning a three-year period and forming the empirical component of my doctoral work, I examine humour as a "quintessentially social phenomenon" (Kuipers 2008: 361) that is often particular to a specific time and place. Speaking to broader themes of sociality, spatiality, embodiment, domination and resistance, I reveal how humour is used by Brother to manage a life lived in public. I also consider how Brother's jovial talk and actions disrupt mundane understandings of 'normal' boundaries. In arguing "agency and structure" collide in the case of Brother, I look at how this evokes a simultaneous "making, remaking, and unmaking" of the person (Hacking 2004).
\end{abstract}

Keywords: homelessness, underdog humour, classificatory processes, social encounters, "making up people", resilience.

\section{Introduction}

An elderly Māori woman and her adult son are sitting on the ledge to Brother's right. Noticing me arrive, he tells them, "Oh oh gotta go to work now". The woman says, "where did you say you were going"? "To work" he repeats in a tone suggesting the activity is an ordinary everyday routine. Looking puzzled for a moment she then turns her attention to me saying "Me and my boy stop most mornings to say hello. This is the first time I've ever seen this, someone living on the street. I'm not from Wellington". As she speaks, Brother ${ }^{1}$ is busily 
gathering up his plastic bag of belongings. "Just getting my briefcase sorted" he chortles. As I wait, a commercial van pulls up and a man leaps out to spray disinfectant around the entrance to the bank to Brother's right. Giving it a cursory mop, he grabs a shirt tie someone has strung above Brother's space, tosses it into the gutter and without acknowledging any of us, hops back into his van and drives away. "Ah good to have the whare (house) cleaned" says Brother who is clearly full of good humour this morning. He is now performing a series of movements shifting off the ground and onto his feet. It is quite a process as he pauses and stretches, grunts and groans; "Ah" he says arching his back and cursing his body, "Bloody old fart bones". The woman watching him asks, "What's the matter does your bum hurt"? Now on his feet and adjusting his blanket more firmly around his body, he chooses to ignore her question. She asks me, "Does he not have a house. Does he not want to live in a house"? I answer no and no as Brother interjects telling me "Come on let's hīkoi (walk)".....

(Fieldwork: 23/06/08)

Humour, as Kuipers (2008: 361) observes, is a "quintessentially social phenomenon" that is often quite particular to a specific time and place. The role of humour as a coping strategy providing a cohesive function in the lives of marginalised and stigmatised groups has been examined in the daily lives of people experiencing social nakedness when undergoing total surveillance (see Coser's 1959 study among hospital patients and Terry's 1997 study on prison inmates). These studies share a focus on the form and nature of collective humour among people of equal status who share common concerns and generalised anxieties. Although a search of the broader homelessness literature revealed that humour in the everyday lives of homeless people has not been studied, a small humour study by Ritchie (2011) has examined the role humour plays in reducing tension in ordinary housed people's conversations about homelessness. For example, humour was found to have a facilitating function in the introduction of "otherwise embarrassing or awkward topics" (Ritchie 2011: 507) in relation to the complex issue of homelessness. While some humour was found to combine an implied denigration of homeless people with a subversive cynicism, some humourous stories also celebrated the humanity of homeless people, including stories in which homeless people were able to beat "the system" in some way (Ritchie 2011).

Previous research has also identified humour as a symbolic resource used by occupational groups. For example, Pogrebin \& Poole (1988) explored the strategic use of humour among police in the briefing room where humour was found to be a valuable resource for testing attitudes, perceptions, or feelings of group members while promoting social solidarity of the group, strengthening group norms and reinforcing the integrity of the occupational working group. The role of humour in the sex industry has also been examined. Arguing that prostitution is an extreme profession where bodily contact is intense, direct and commodified, Sanders (2004) identifies humour both as a business technique and a psychological distancing strategy in order for sex workers to manage the emotions of selling sex.

While there is much talk within sociology about patterns of inclusion and exclusion of stigmatised groups and persons, and many studies on homelessness address this very issue (see Miller 1991; Mitchell 1995; Phelan et al. 1997; Ferrell 2001; Amster 2003; Clapham 2008), a review of the literature clarified that, aside from a few notable exceptions (Duneier 1999; Nicholls 2009; Parsell 2011), insight into the agency or intentional social actions of homeless persons within the contextual setting where they are enacted has been marginal. Also absent from existing discussions is any notion of wellness among homeless people or any suggestion that playful elements could infiltrate the day-to-day business of "doing street life". In short, academic writing on the experiences of homeless people proposes homelessness is hopelessness and that a street life existence is essentially "no laughing matter". 
The introductory street scene I described earlier contests that view. It illustrates an ordinary member of the public attempting to make sense of Brother's life on the street. Her questions are fobbed off by Brother, who, instead of answering them seriously, combats her curiosity with nonsensical retorts. His humorous explanations about going to work, packing up his briefcase and getting his whare cleaned, challenge any suggestion that he is 'homeless'. Rather, he playfully aligns himself with activities normally associated with house dwellers and conventional obligations normally associated with that lifestyle. My fieldwork material, therefore, represents a significant departure from the categorisation of homelessness and the category of homeless people themselves as marginalised and subjugated, as is predominately discussed within the homelessness literature (see Snow \& Anderson 1999; Lee et al. 2004). Within such accounts, homeless people are usually described as suffering "nonperson" treatment, that is, stigmatised individuals are often treated by others as if they are not there at all, they are "objects" not worthy of even a glance (Goffman 1963: 85). Contrasting with that dominant portrayal, Brother has a marked presence on the street and in the public imagination of many Wellingtonians. In fact, he is a street person who has become something of a legend, at least in the Wellington environs.

Classifying or categorising others is a human tendency. It is how we make sense of who the other is and where they can be understood to fit in - or not, as is sometimes the case. In New Zealand where direct exposure to street homelessness is far less frequent than that experienced overseas (O'Brien \& de Haan 2000; Wellington City Council 2004), many people have limited objective knowledge regarding homelessness. Therefore, as Phelan et al. (1997: 325) observe, their perceptions are

likely to be influenced strongly by a small number of highly visible homeless individuals visible either in the media or in their local community - who become salient because of their unusually dangerous, disruptive, or unaesthetic behaviour or appearance... [which] may cause people to overestimate the prevalence of these characteristics in the homeless population.

This article explores how Brother uses humour to resist and challenge ongoing categorisation and social control processes that simultaenously act to classify him a 'bad, mad, and sad' homeless man. As a person choosing the street corner as home, Brother is thus open to natural reactions and social control interventions confronting his blatant thwarting of social norms. While Brother's practice of making light of his everyday experiences has contributed to an established jocular personality, I reveal how humour can also be used to play with boundaries. I demonstrate that Brother, like Sander's (2004) prostitutes, has strategically developed interactional methods that give him some control over what he defines as his particular "occupational hazard" (Brother: 27/02/10), that is, the 24 hour scrutiny and interference of other people. In arguing "agency and structure" collide in the case of Brother, I suggest an underdog humour is also at play. Significantly, then, while Brother's motive for doing humour is, as Kuipers (2008) work suggests, "quintessentially social", I contend his methods for executing humour become an interactional accomplishment that can both fail or succeed "sometimes in concert with people, sometimes in opposition to them, but always in relation to them" (Hull \& Zacher 2007: 75).

Brother's underdog humour is revealed through a repertoire of talk and actions identified here as his 'tricks of the trade' that enable him to 'make himself up' both in how he experiences being a person, and in how he would like others to see him during social encounters. This humour is identified to have several roles. First, underdog humour functions as defiance; it becomes a playful form of rebellion against authority, and provides another means by which to alleviate boredom and relief from mechanical routine. Second, Brother's command at turning an extreme existence into one of jest intends to impart a sense of his own 
autonomy over his 'home' territory in public space. This is particularly in regards to those holding positions of power -the 'top dogs'- whom Brother knows, can, on the basis of their authority, intrude anytime they wish on his personal life. Third, underdog humour, commonly exhibited in provocative and sometimes outrageous one-liners, allows Brother to retain dignity and status by enabling him to get in first so as to diffuse anticipated responses to his stigmatised identity. For example, a frequent, if not daily, one-liner is the self-mocking proclamation, "I am the last ugliest dumb cunt left in Aotearoa". Although this selfdepreciation humourously conveys that he is an endangered species, it also refers seriously to his perceived 'otherness' brought about by his choice to live on the street. Here, as Ungar's (1984) work argues, one is able to take refuge in self-mockery. Fourth, underdog humour plays with stereotypical understandings of madness to contest medical monitoring. However, it is counter-argued that humour used here also functions to allay any underlying associated anxiety that may be experienced in the face of medical scrutiny and testing.

Methodologically, my work is located within the 'ethnography of everyday life' studies in sociology which view ordinary life as extraordinarily complex. A critical concern is to use my data in ways which emphasise Brother's agency. Building from Goffman's (1959; 1961) writings on the face-to-face encounter and Garfinkel's (1984) and Sacks' (1992) insights into social interaction as an accomplishment, humour is recognised in this article as an interactional resource with considerable strategic and contextual relevance. This position builds on the relevance of the Chicago School's attention to detail by taking seriously the implications of the routine observability of social activities. That is, a key methodological principle emphasises the need to focus sociological descriptions on the techniques people use to produce sensible social activities that fit with those they see happening around them. The analytic task is to demonstrate through the situatedness of talk and action how meaning in humorous interaction is locally produced and understood (Silverman 1993; Francis \& Hester 2004).

Inspired by the longstanding tradition of street corner sociology, my research is grounded in a commitment to relatively open forms of ethnographic research including participant observational field work conducted over a three-year period from January 2007 through to July 2010. Approximately 400 hours were spent sitting alongside Brother at ground level in the thick of the pedestrian flow wherever he happened to be: on the street corner, outside shops or banks, in pedestrian malls, or in city parks. Many kilometres were also covered walking in and around the city when expanding the boundaries of my study to accompany Brother using the hìkoi method. ${ }^{2}$ These excursions included visits to The Community Law Centre, The Downtown Community Ministry, ${ }^{3}$ Work and Income New Zealand, ${ }^{4}$ the Courts; High, District and Court of Appeal, banks, a local printing business, as well as brief visits into retail outlets to purchase food or alcohol. I also made several visits to Brother in Ward 27 (Wellington Public Hospital's Psychiatric Unit) when Brother was committed by a District Court judge enforcing a compulsory treatment order despite two psychiatric assessments prepared for the court that had declared him mentally fit. By extension, my street ethnography included observing Brother's interactions with a diverse blend of people: other street people, commuters, shoppers, young children, retailers, tourists, buskers, drug dealers, a professional photographer, street cleaners/wardens, police officers, judges, and psychiatrists.

This article will now introduce Brother before going on to explore the question of how Wellington street people are singled out or collectively grouped, named, and categorised. Drawing from newspaper coverage focused on Brother aka Blanket Man, I examine how homeless people themselves are categorised in newspaper reportage on homelessness. Following this, I position the thinking, joking, talking, laughing individual at the centre of analysis to consider, in the remainder of this article, how Brother 'makes up' 
himself to simultaenously resist classifactory regimes that respond to his resilient choice to live his life as he sees fit. Here, underdog humour will be shown to have a nuanced but pivotal role.

\section{Who is Brother?}

Brother is a well known street person who arrived in Wellington from the Waikato during the summer of 2001. He quickly became known for living his private life in public through his full-time occupation of footpath space in a busy city location. Before long, the Wellington newspaper media reported on his arrests and subsequent court appearances for public law breaking: smoking marijuana, breaching the liquor ban, offensive behaviour, and obscene language. Over time, this media attention brought out other aspects of Brother's character, including his ability to treat his situation as humorous. For example, once when appearing for sentencing he asked for 'home detention'. By 2002, in media references to a group of 'hard core homeless' who centred on a small city park, Brother was reported to have a leadership role among this homeless group. In November 2002, Brother received a spate of media publicity when he was legally prohibited from entering a major inner city pedestrian mall and went on to establish a 'village of peace' with other homeless individuals at the Cenotaph in Parliament grounds. This protest lasted five weeks and some of it was captured in a film documentary Te Whanau o Aotearoa: Caretakers of the land (Wright \& King-Jones 2003), later aired at the Wellington Film festival in 2003. Brother is the key character in the film. Today, Brother chooses to live alone in one or two favoured sites, interspersed with time spent in prison and, more recently, a period in the psychiatric ward.

Media reportage on Brother is almost always focused on his law breaking behaviour. Further, language used by the media has variously described him as a "manky nomad" (Tratt 2005) or an "urban Tarzan" (Urban Tarzan 2007), reinforcing his status as feral and posing a menacing threat to the public. Because Brother presents as an anchored presence through his choice to dwell ' $24 / 7$ ' on busy city street corners, everything he does -from smoking cannabis and drinking alcohol, to sleeping or basking near-naked in the summer sun- is highly visible to others, including the intrusive lens of the media's camera. Consequently, media reportage and accompanying images of Brother are usually focused on his illegal behaviour that occurs in public. This projection of Brother portrays him as a social problem and as a type of person for whom the consequences of intervention and containment are unavoidable, for his 'own good' and for the wider interests of the city.

In the simplest interpretation, media constructions and associated images relating to Brother (only briefly sketched here) project a notion of a 'bad' homeless person. The work of Hodgetts et al. (2010) and Laurenson \& Collins (2007) has also picked up on the media's tendency to contrast reports of 'bad' homeless people with portrayals of 'good' homeless people (see also May 2003). This media construction of Brother produces an ominous impression. The media also elected to refer to Brother as Blanket Man, and so too did many people I observed interacting with Brother at the face-to-face level of the street. Though such naming may seem innocuous and while "[n]aming alone is never enough to create" (Hacking 2002: 8), it nonetheless objectifies Brother and draws attention to his frugal belongings. Crucially, as Hacking further notes, "naming occurs in sites, in particular places, and at particular times. For a name to begin to do its creative work, it needs authority. One needs usage within institutions. Naming does its work only as a social history works itself out" (2002: 8).

Language used by the media in more concerted efforts to construct 'good' and 'bad' faces of homelessness more clearly fulfils and achieves such an agenda. As Hacking (2002: 
9) points out, "[n]ames do not work alone, as mere sounds or signifiers. They work in an immense world of practices, institutions, authorities, connotations, stories, analogies, memories, fantasies". Certainly, in the case of Brother, media organisations played a pivotal role in naming, constructing, and categorising - contributing to a notion of 'bad' homeless person becoming synonymous with the name Blanket Man. Indeed, categorisation practices were and are occurring within the bureaucratic space of local politics. This was made evident in Laurenson \& Collins' (2007) study of local government regulation of homelessness in New Zealand, with one city planner lamenting, "depending on what the context is we have lovely homeless and don't we care about them, don't we love them, and ghastly homeless, and we get awfully muddled" (Laurenson \& Collins 2007: 663).

\section{The "making, re-making and unmaking" of a person}

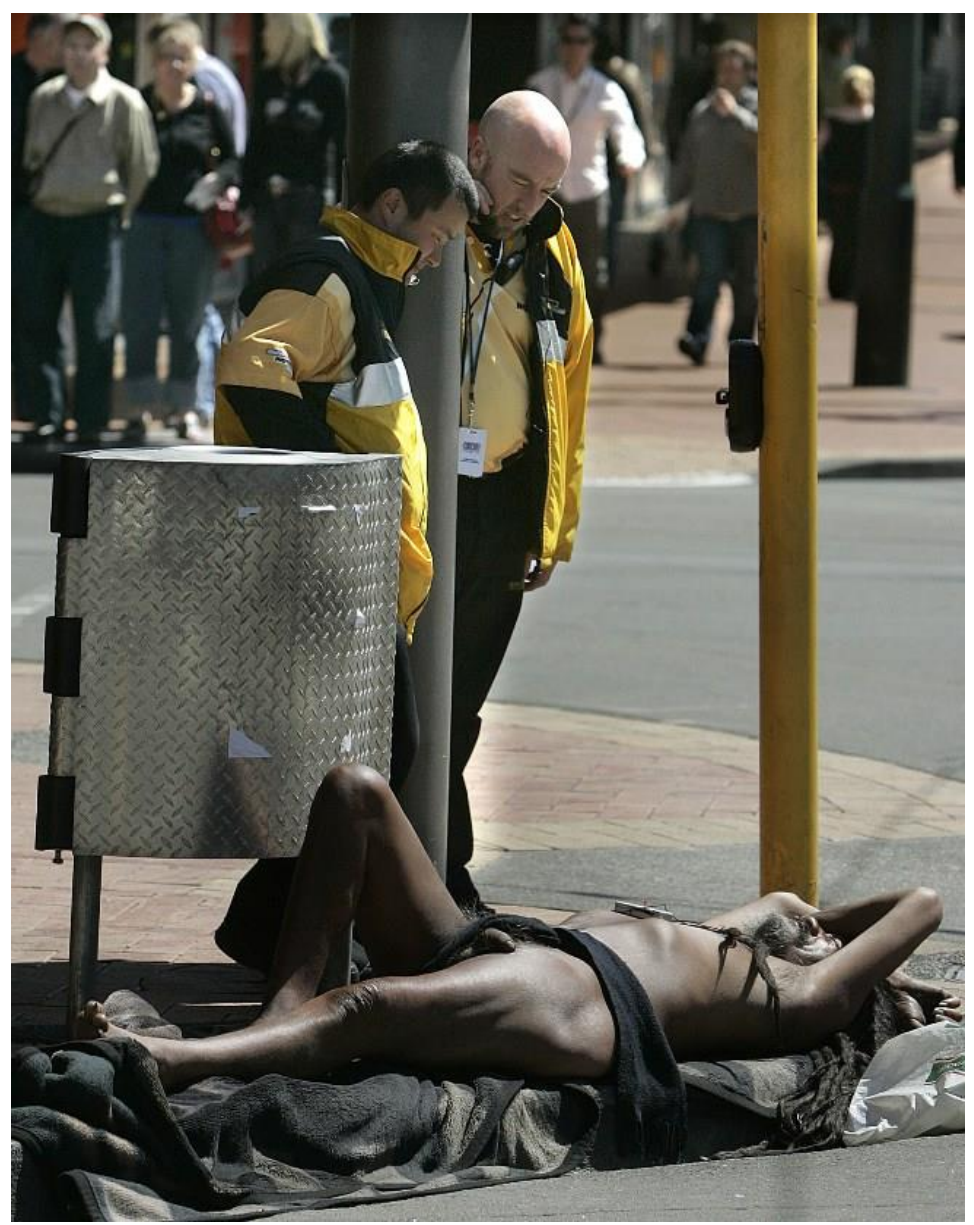

Figure 1. Brother, afternoon napping in his city-as-whare

Source: Copyright Fairfax Media

At the same time as constructions of homeless people are fed into the public imagination via newspaper rhetoric, anyone passing through Brother's home locale can see for themselves Brother living everyday life on the street corner. The above image graphically captures Brother basking at home in the city he calls his whare as he cuts a familiar sight occupying space on the cityscape. This image also shows two Walkwise officers ${ }^{5}$ standing over the sunning snoozing Brother whose loincloth has slipped revealing his genitals. Although in New Zealand, in the absence of anti-homelessness legislation, it is not an illegal state of being to live one's life in the public realm, it is nonetheless this particular "presentation of the 
self" (Goffman 1959) coupled with his regular private-in-public activities, that I argue becomes the most troublesome to others. Visually, and at a mere glance, numerous transgressions between clean and dirty, ordered and disordered, normal and deviant, legal and illegal, rationality and irrationality, dressed and undressed, are all too possible. To an extent, Brother's cavalier attitude and his tendency to amp up a pleasurable state of being while dwelling in the harsh terrain of the city street is discernible to others. This can trouble common understandings associating homelessness with hopelessness. Impressions people form based on what they see and how they interpret or socially construct what they understand to be happening in a given context, therefore contributes to the ways we make up people.

Although it may be 'street legal' to take up a city corner as home territory in Aotearoa, New Zealand, poor public attitudes and intolerance of homelessness impacts upon the way homeless people are dealt with by authorities. As Mitchell (1998) contends, handin-hand with constructing the other as disorderly, it becomes necessary to locate some aspect of their behaviour and make it illegal. Despite assertions that this, in a positive sense, does not target the 'status' of individuals but the 'conduct' of such individuals, targeting behaviour nonetheless becomes the vehicle used to marginalise people perceived to be undesirable from public view (also see Duneier 1999). Indeed, in the Wellington case, my research discovered that responses to homeless people perceived as a problematic societal category include attempts to monitor, control, and curtail the activities of homeless people in social space by targeting activities associated with homelessness for example, public sleeping, begging, or being intoxicated in public. As one newspaper article reported, the Wellington's City Council's initiative is one pledging "to cleanse the streets of human detritus" (Bylaw tweaking is a risky business 2004). The result is that an everyday concern for those who are homeless becomes one of balancing the tension between 'home' territories they regularly frequent (Wilkinson 1980), and these public spaces, which are simultaneously open to all persons, and also regulated by the institutions of social control (Phelan et al. 1997; Amster 2003; Lee et al. 2004).

For nearly a decade, usual social control measures responding to Brother's regular private-in-public activities -smoking cannabis, street drinking, or his use of offensive language- resulted in frequent arrests and subsequent fines, or trespasses from various city spaces, sometimes simultaneously, interspersed with periods spent in prison. One of the more unusual responses occurred when a District Court judge imposed a court order ruling he wore underwear in public (Fawkes 2009: A1). However, behind the scenes, this was not all that was happening.

\section{Examining re-classification-in-action}

In 2009, in response to Brother's continued offending, legal interventionist processes began to include a monitoring of Brother's mental health by more actively probing whether any physiological or psychiatric condition could account for his persistent offending and different way of being in the world. In line with this development, Brother sometimes made a mockery of the questions he was asked by health professionals. For example, he had told them, "I listen to dead people" and "I boogie with the dead" in response to the question, "Do you hear voices?" (Fieldwork: 16/01/09). Yet, while he was making fun of the assessment process, he was also giving answers that made logical and contextual sense to him given he was referring to his regular pastime of listening to music including many favourite (deceased) musicians Hendrix, Marley, Morrison, Joplin, and so on. During one corner conversation, and after he had recently undergone another court ordered assessment, Brother had relayed "Have seen 
another psycho (psychiatrist) down at the court house. I told him I time travel and that I'm currently enjoying 1984". He had laughed heartily and said, "I play with madness". Then, after a brief pause he had turned to me smiling and again dryly referencing Orwellian thinking, had added, "That'll give them something to think about with all their surveillance tactics eh" (Fieldwork: 04/11/09). Here, Brother's joking quips illuminate his 'dissing' of the assessment process and those he felt were "working the system... pulling that mental health thing on me". Although he was aware that his 'piss taking' antics could be taken as "crazy talk" (Fieldwork: 26/07/08), he also wagered that by keeping his wits about him and responding to clichéd 'text book' questioning in like manner, that those 'doing the probing' would come to see he was 'on his game'. That is to say, the joke was on them and he would then enjoy the last laugh (Fieldwork: 16/11/09). At the same time, Brother's method of humorously playing with stereotypical (mis)understandings of madness can also be understood more seriously as enabling him to ward off any anxiety he may also be experiencing when dealing with this complex force infiltrating his daily life.

Then, in March 2010, Brother mentioned that the police were no longer interested in arresting him but that "the psychos" had assessed him again. In May 2010, during another conversation had on a quiet 7am street where Brother talked about the ongoing "tactics" of those in authoritative positions who "are still trying to CAT scam [sic] me", ${ }^{6}$ he had also commented, "I can't even get arrested anymore. The rest of them (street people) are still going to the slammer though". Understanding that on one level Brother almost welcomed the odd brief night spent in police custody, or even a short prison sentence that also helped combat the cold and bleak winter experience, I nonetheless sensed he was beginning to feel unsettled now that it appeared to be 'game over' with the police turning a blind eye towards his public offending - chiefly his smoking of cannabis and street drinking. Moreover, as I was able to appreciate in time, Brother relished his encounters with the police as they monitored his actions on the street. Such interactional episodes provided another social conduit through which he could create a sense of fun and games for his self - games that he sometimes won, sometimes lost, but always enjoyed. I had talked to him about the medicalisation of deviance process, also surely explaining that those in authority -the justice system and mental health professionals- were now collaborating more frequently on what to do about the 'social problem' that he continued to pose by living and acting however he chose in public space. Brother, listening intently and understanding the simplified (nonacademic) sociological reasoning I was offering, had told me that at least he knew where he stood when under the radar of cops and courts but that he did not trust the "tactics of the psycho's and their CAT scamming [sic] bullshit". I also cautioned him that his humour 'playing with madness' - to the psychiatrists could potentially backfire. He replied that he had told the court that he did not want to be medicated or treated and that he was being careful playing them at their own game (Fieldwork: 22/05/10).

Towards the end of May 2010, when again sitting with Brother observing, he had randomly asked me whether I had ever been to the South Island. He told me that he had not made it there himself yet (Fieldwork: 28/05/10). Several days later and Brother's talk about the South Island was to gather significance when I read in The Dominion Post that he had travelled by ferry to the South Island and was to appear in the Blenheim District Court on charges relating to his public cannabis use on the ferry (Wong 2010). Accompanying the story was an image of Brother sitting on the street outside the court. His court appearance in Blenheim resulted in his being flown back under police escort to appear in the Wellington District Court. Remanded at large afterwards and catching up with him on the corner several days later, he had seemed pleased with his break in routine which had given him experiences of getting to the South island, sailing on "the big waka (ferry)", and flying in a plane for the first time (Fieldwork: 10/06/10). When next reappearing for sentencing in the District Court 
in June 2010, District Court Judge Paul Barber, despite hearing the assessments of two psychiatrists finding Brother mentally fit, committed him under Section 34 of the Mental Health Act $^{7}$ to Wellington Hospital's Ward 27 (Hunt 2010).

So, how is it possible to understand how Brother became a subordinated person incarcerated within a psychiatric ward when all psychological and physiological testing prior to that had consistently found him mentally fit?

To begin to answer this, Hacking's theorising about how people are made up identifies the way the "community of expert knowledge" (Hacking 2007: 285) can create a reality from above. In contrast to this, Hacking (2002) also recognises that the vector of the autonomous behaviour of the person that is labelled can press from below and create a reality that every expert must face. These claims are useful for understanding the longstanding battle of the wills that persisted between lay people and the authorities versus Brother, a street dweller flouting an "I do and I don't give a shit" mindset as he 'lives it up' and enjoys a hearty good laugh doing things his way in prime social space.

Until Brother's committal (and beyond) I observed how he pushes normative and acceptable boundaries between commonly understood codes of appropriate public/private and illegal/legal behaviour. Moreover, he does not always do things his way in a quiet or discreet manner. Indeed, at times his actions seem to invite controversy. Yet, as I have demonstrated, much debate and action arises in response to his use of public space and the activities he routinely conducts in these spaces. Brother was first ordered through the courts system to undergo a mental health assessment in 2003 and as was documented in the film Te Whanau Aotearoa: Caretakers of the Land (Wright \& King-Jones 2003), the assessment found him functioning within "normal mental capacity". Investigations into Brother's mental health did not then gather any notable momentum until 2009. In the interim, the standard official response to Brother's breaching behaviour was to arrest him, charge him and punish him which, as discussed, included him spending periods in prison. Hacking (2002: 11) suggests however, that as people become aware of how they are classified, their behaviour can change in conjunction with the classification. In Brother's circumstances, my observations repeatedly found that he remained rebellious to the labelling of him as 'a criminal' and the associated consequences meted out by those with the power to enforce law and order responses that came with that label. Contrary to Hacking's articulation, Brother did not alter his ways or clean up his act. Instead when conflict did occur, it seemed to buoy Brother along in his steadfast resolve to live his life as he saw fit. For example, in observing Brother's routine breaching of the city liquor ban, he often illustrated his defiance through provocative statements founded on a finely honed repertoire of humour all made within the earshot of patrolling police officers, such as "Liquor free zone at all times" or "Let's get him with the liquor ban" (Fieldwork: 05/12/08). As he once put it to me after this met with police confrontation, "They persist, I resist" (Fieldwork: 30/05/09). Clearly, for Brother, breaking the law is something that can be laughed at and about. Furthermore, Brother's promotion and consumption of liquor (and at other times cannabis) more often than not elicited a great deal of encouragement from members of the public observable through their affirmative hand signals -the 'peace' or 'thumbs up' signs- voiced endorsements and donations of alcohol or drugs. In this context, acting humorously and treating his confrontations with the police in a joking manner arguably enable him to resist the narrative of (police) victimhood in the eyes of others, and define his own identity as an individual who is in command and able to mind his self. However, even as he maintained his street life in the face of sanctions, he also complied at times with court orders temporarily forbidding his presence in certain spaces. Moreover, he is also committed to wearing underwear in public, albeit under his loin cloth.

Over time, as the trajectory has highlighted, the "community of experts" -justice personnel and health professionals- renewed their earlier concern by more actively 
questioning the mental health status of Brother. The growing idea that mental impairment could be affecting his ability to make 'proper' decisions, triggered a process wherein the Brother as 'criminal' classification was deconstructed and replaced with a new classification of Brother as 'mentally ill'. Consequently, this trajectory can be seen to align with Hacking's observation that the 'community of expert knowledge' can create a reality from above.

On the other hand, as the data have simultaneously shown, Brother's aberration from fairly predictable monotonous routine of almost ten years standing, that saw him leave his home locale and travel South also accords with Hacking's (2002) observation recognising the way "people who are medicalised, normalised, administered, can increasingly try to take back control from the experts and the institutions" (Hacking 2002: 12). Put simply, as Brother became increasingly aware of mounting scrutiny deployed by 'the community of experts' seeking to reclassify him, he resorted to taking more radical action himself in order to avoid the net he sensed closing in around him. In doing so, however, he extended his being in an unprecedented way, which signalled trouble to the 'community of experts'. Why? Because Brother, now geographically removed from his locale of Courtenay Place and the site of sustained monitoring, became what Hacking (2002) would describe as a moving target at which intervention then must aim. The swift legal response that intervened to return Brother back to Wellington certainly supports this claim. Further, the judicial decision-making that subsequently committed the 'bad/mad' homeless person into psychiatric care fits with Kawash's (1998: 330) view: "if the homeless... [body]... cannot be eliminated or erased, then at least it can be shrunk down, isolated, and contained so that the public need not feel the pressure of its presence". Moreover, Goffman's (1961b: 248) assertion holding that "[j]ust as we fill our jails with those who transgress the legal order, so we partly fill our asylums with those who act unsuitably" is given empirical weight and contemporary impetus when aligned with this judicial action.

Central to Hacking's (2002) "making up people" is a concern with the way classifications, when known by those classified or those around them, get put to work in institutions changing the ways in which individuals experience themselves. Hacking goes further saying that "Such classifications (of people and their behaviour) are interactive" as the classification and the individual classified may interact once the individual becomes selfaware of a particular classification, if only through being treated or institutionalised in a certain way therefore experiencing themselves in that way (Hacking 2002: 11). Moreover, for Hacking, this can create a situation wherein current systems of diagnosis and treatment themselves help to produce the kinds of disturbed behaviour characteristic of the illness. He writes: "the classification and diagnosis is constructed, and this very construction interacts with troubled people and helps to produce their behaviour which in turn confirms the diagnosis" (Hacking 2002: 10). In light of these arguments, one final question remains: Could Brother, as a committed psychiatric patient, be observed to interact with his new classification and did he come to fit his category?

I made several visits to Brother while he was in the hospital with the following vignette providing an insight into one of my earlier visits:

"This is what happens when other people think for you", Brother tells me as we sit in the cold barren courtyard of the psychiatric unit. Aside from us, there is only one other person out in the yard who has chosen to sit right beside me on one of the wooden bench seats. Brother, wrapped in his blanket, sits to my right assuming the cross-legged stance he adopts on the street. The woman beside me starts coughing, a violent phlegm filled attack. Leaning forward now and gasping for air, she splutters spittle while stamping one foot up and down on the ground as she struggles to gain control. As the coughing fit subsides, she sits up straight and soothingly pats her chest before turning her attention to the unlit cigarette held in her other hand. The three of us sit in silence as pigeons meander at our feet pecking fruitlessly at the 
concrete surface of the yard. As I absorb Brother's insight concerning his present situation and wait to hear whether he will elaborate, the woman patient beside me spontaneously breaks into song. I am immediately struck by the sheer power and beauty of her voice as her rendering of Green green grass of home quickly reverberates filling the air. Brother continues now "Their rules, this is not my life I'm living". He pauses, now adds, "They say I'm a transient" (his emphasis as he tries out a new classification). "That makes me a nutter in their thinking". Spoken within this bleak secure place known simply by many as 'Ward 27', I silently wonder if this latest confinement, which, is far removed from home as he chooses it out on the street, will become his final stop. As the woman's poignant longing for home continues to sound, he echoes my thoughts saying "They'll never let me out". I decide, "They can't keep you here forever. All you can do for now is keep keeping it real". "Ah" he replies, while looking at me and grinning wryly, "We'll just have to wait and see what their politically correct way says next."

(Fieldwork: 20/06/10)

Striking within the vignette is how Brother is rendered impotent under what he identifies as their thinking and their rules. Clear within his utterances, is an acute awareness surrounding an almost total loss of agency experienced as a confined patient in Ward 27. By virtue of his new status, he is now deprived of many of his legal rights. His freedom of movement is severely restricted, his personal hygiene is monitored, and his body is injected with psychotropic drugs. In terms of the latter, and as he put it to me on more than one occasion, the medication interacted with his sense of wellbeing with Brother identifying "the pills make me morbid" (Fieldwork: 02/07/10). Crucially, the vignette identifies how a new classification and the associated responses which led to the confinement of the now 'mad' transient person can be seen to impact on Brother's ability to live life how he would choose it. Ultimately, he clearly and keenly feels the effects of the reclassification of Brother as mentally unwell, as they interact and change his daily experience.

Overall, however, whatever the 'community of expert knowledge' tried to do with their categories, that is, whether they criminalised or medicalised Brother's expressions of agency, he is nevertheless able to retain his grip on acting autonomously, and usually in a jocular manner. For example, my discussion has also alluded to how my visits to Brother in the ward found him maintaining his way of doing things wherever this was possible. He elected to spend his time outdoors sitting on the ground in the courtyard; therefore only returning indoors when evening lock up dictated. He continued to maintain a sense of humour where he was able, for example, telling me one evening upon my arrival, "News flash, I'm having a bath tonight [pause], apparently", while elbowing me playfully in the ribs and expressing a look of mock horror. He continued to wear his blanket as clothing. And although he eventually relented and slept on a mattress upon the floor, he never availed himself of the conventional bed option that was on offer in the room.

Brother's case and in particular his desire to hold onto his sense of self as described here within the psychiatric setting, exemplifies the ongoing relevance of Goffman's work for contemporary scholars. In particular, Goffman's articulations of stigma and total institutions are useful for they observed the way, after admission, patients strived to retain the image of oneself that one wanted to present to others, even as this came under attack by the institution's rules. For Brother, though he had strived to maintain his usual image of the self, he could do very little about the trembling of his hands that was caused by the anti-psychotic medication he was required to take. When ruminating about this, on several occasions, it became clear to me that he was experiencing what Goffman termed a violation of the territories of the self. That is, through the medication, his body let him down: Goffman's (1961a) "mortification of the self" manifested. Here, Brother's response fits with Goffman's theorisation of "looping" - the unmaking of the person which, to reiterate, encapsulates the 
cyclic effect of responses to humiliation that are experienced at the inter-personal level of face-to-face interaction.

After some months spent solely within the confines of Ward 27, Brother was discharged from the hospital and was again free to resume his city-as-whare life so long as he complied with medical stipulations that had set the terms and conditions of his release. Notably, these conditions included wearing what could now be more aptly described as 'medically prescribed' boxer shorts. This latest concerted effort to modify and thus rectify the way in which Brother prefers to present his self to others, accords with Hacking's (2007: 309$311)$ contention that as a society "[w]e medicalise kinds of deviant people relentlessly, not always with success... In many cases, we try to make unfavourable deviants as close to normal as possible". Yet, this stipulation, like the court ordered underwear that had preceded it, spurred Brother's urge to 'play' with the limitation it imposed. That is, the "underwear fiasco" (Fieldwork: 17/01/09) as Brother termed it, presented ongoing opportunity for him to 'take the piss' and assert his autonomy in how he preferred to appear in public. Thus, today he can be seen wearing both the underwear and the boxer shorts beneath his loin cloth. Here, Brother's ability to poke fun at that he must tolerate at times, resonates with Goffman's (1961b: 133) assertion that individuals can act to say "I do not dispute the direction in which things are going and I will go along with them, but at the same time I want you to know that you haven't fully contained me in the state of affairs".

\section{Conclusion}

Brother's command at turning an extreme existence into one of jest has been shown to simultaneously subvert the ascribed membership category of homelessness and trouble normative understandings about how street life can be experienced. However, with those in authority, 'the experts' (or 'top dogs') failing to accept that someone could choose to take up the street corner as home, Brother's execution of humorous resistance to classificatory regimes responding to him as a 'social problem', that is, a criminal and then mentally unwell individual, unsettled those doing the naming. I have revealed that while an unexpected degree of joking relations is readily identifiable in Brother's talk, much of the banter used by Brother, particularly jovial quips that played with madness and uttered within medical encounters, inevitably backfired, as the meanings behind them were not commonly understood by all participants. Rather, Brother's underdog humour signalled the ramblings of a mad man, thus serving to reaffirm growing suspicions that he needed to be contained and medicalised for his own good. Although I do not suggest Brother should be able to flout his private activities in public -smoking cannabis or breaching city liquor ban prohibitions- and remain immune to laws everybody is expected to abide by, I have endeavoured to emphasise how it was Brother's different way of being in the world that was profitably problematised into a psychiatric trouble. Ultimately, his chosen state of homelessness eventually became a diagnosis. Countering this, from Brother's perspective, he has a home; he 'knows his place'. His lived reality of what others see as 'homelessness' is not, by his own making, a state of 'hopelessness'. It is this subjective view, of course, and the visible social action it produces that I have attempted to convey rests at the crux of the social problem Brother symbolises for 'the (housed) other'.

Engaging Hacking's (2002) framework to understand how "making up people" occurs in a more abstract sense, in line with Goffman's work leaning towards more empirically understanding how a making inevitably exists in the 'unmaking of the person', a platform for making scholarly sense and analytical links between the shifting classifications has been possible. Although I have provided an examination of but one individual, Brother's case, 
when positioned within an "inference rich" (Sacks 1989) context of homelessness, speaks to how generated forms of knowledge surrounding classifications -both popular and expert-can shade into each other and gather momentum, particularly "within institutions that guarantee their legitimacy, authenticity, and status as experts" (Hacking 2007: 297). As demonstrated, this knowledge loops back to affect on-the-ground experiences of those 'doing homelessness', and the experiences of others, like Brother, who dare, or are impelled, to do things differently. By extension, my examination aims to contribute empirical knowledge about the implicit role humour can be seen to have in the life of a person attempting to resist and combat an enduring process of classification and re-classification.

\section{Afterword}

Brother died suddenly and unexpectedly in January 2012. Prior to his death, my home visits to him that I continued from time-to-time beyond the data collection phase of my research, encountered a very changed mood. Living under the shadow of a psychiatric classification, Brother had simply existed. His zest for life had all but evaporated, his body trembled, his appetite was poor, and his daily nap dominated his day. At the same time, his joking banter slowly dried up. Yet, he was not physically unwell. Brother, himself blamed the pills that kept him medicated and were duly administered to him on a daily basis by a mental health worker on the street corner. Brother's demise powerfully resonates with Hacking's (1995) suggestion that people classified can change in conjunction with the way they have been classified, with what they believe about themselves, or because of the way they have been treated. To this end, it is fitting to conclude with a few of Brother's own words, taken from one of his campaign street posters. These words are symbolic of the philosophical vision that propelled his choices and actions throughout the final chapter of his life's work:

\section{R.E.S.P.E.C.T \\ E Toa! Hine Toa! Te Hei Mauriora \\ We Shall Carve A Vista More Than A Sense Of Being "More" Than A Feeling Belonging - Participation - Involvement - The Freedom Of Choice Is Ours}

(Brother, 2009)

\section{Notes}

1. In compliance with Bernett Hana's wishes, I used his preferred name of Brother in my communication with him and subsequently I adopt this name when referring to him in my research. Brother, is however, addressed by a public-at-large using a variety of colloquialisms including Blanket Man, Blanket, Bro, Ben, Cave Man, Bernard, and Tarzan. However, the most prolifically used name heard throughout my field work was Blanket Man in recognition of Brother's ever-present blanket providing him with clothing, cushioning, and warmth for his body.

2. The word hīkoi translates to mean "step out, plod, pace" and is often used by Māori to describe a significant spiritual journey (Ryan 2001). In my research the hīkoi method was named by Brother and given life through his invitation encouraging me to actively observe and interpret his experiences and practices in situ in other sites. 
3. In Wellington, The Downtown Community Ministry's primary purpose is to provide support and advocacy to disadvantaged and marginalised people who frequently have backgrounds of homelessness and/or drug, alcohol or gambling addictions.

4. Work and Income New Zealand is a government agency providing financial assistance and employment services throughout New Zealand.

5. Walkwise officers are employed as 'city ambassadors' by the Wellington City Council. Their walking presence is designed to prevent and reduce crime and anti-social behaviour through their visibility.

6. Here, Brother is referring to a court-ordered CAT scan. CAT is an acronym for a Computed Axial Tomography (brain imaging) scan that is increasingly applied in psychiatry both for clinical evaluation and as a research tool. Sometimes a CAT scan is used to look for any organic abnormality or problem such as a brain tumour or bleed that could be treatable and could be causing behavioural issues in some people (Netdoctor 2013).

7. Section 34 refers to the Mental Health (Compulsory Assessment and Treatment) Amendment Act 1999 which, as the explanation suggests, gives judicial power to the courts to impose compulsory treatment orders on people.

\section{References}

Amster, R. (2003). 'Patterns of exclusion: Sanitizing space, criminalizing homelessness'. Social Justice 30 (1), pp. 195-217.

Bylaw tweaking is a risky business. (2004). The Dominion Post, April 26.

Clapham, D. (2008). 'Homelessness and social exclusion', in Abrams, D., Christian, J. \& Gordon, D. (eds.), Multidisciplinary Handbook of Social Exclusion Research, Chichester, England: John Wiley \& Sons, pp. 79-94.

Coser, R. L. (1959). 'Some social functions of laughter: A study of humor in a hospital setting'. Human Relations 12 (2), pp. 171-182.

Duneier, M. (1999). Sidewalk. New York: Farrar, Straus \& Giroux.

Francis, D., \& Hester, S. (2004). An Invitation to Ethnomethodology: Language, Society and Interaction. London: Sage.

Garfinkel, H. (1967). 1984. Studies in Ethnomethodology. Cambridge, England: Polity Press.

Goffman, E. (1959). The Presentation of Self in Everyday Life. Garden City, NY: Doubleday.

Goffman, E. (1961a). Asylums: Essays on the Social Situation of Mental Patients. Garden City, New York: Anchor.

Goffman, E. (1961b). Encounters: Two Studies in the Sociology of Interaction. Indianapolis, IN: Bobbs-Merrill Company.

Goffman, E. (1963a). Behaviour in Public Places: Notes on the Social Organization of Gatherings. New York: Free Press of Glencoe.

Goffman, E. (1963b). Stigma: Notes on the Management of Spoiled Identity. Englewood Cliffs, NJ: Prentice-Hall.

Hacking, I. (1995). 'The looping effects of human kinds', in Sperber, D., Premack, D. \& Premack, A. (eds.), Causal Cognition: A Multidisciplinary Debate, New York: Oxford University Press, pp. 351-383.

Hacking, I. (2002). 'Inaugural lecture: Chair of Philosophy and History of Scientific Concepts at the Collège de France (16 January 2001)'. Economy and Society, 31 (1), pp. $1-14$.

Hacking, I. (2007). 'Kinds of people: Moving targets', in Marshall, P.J. (ed.), Proceedings of the British Academy, Vol. 151, pp. 285-318. 
Hull, G. A., \& Zacher, J. (2007). 'Enacting identities: An ethnography of a job training programme'. Identity 7 (1), pp. 71-102.

Hunt, T. (2010). 'The man behind the blanket: Courtenay Place won't be the same without him'. The Dominion Post, June 19, p. 4.

Kawash, S. (1998). 'The homeless body'. Public Culture, 10 (2), pp. 319-339.

Kuipers, G. (2008). 'The sociology of humour', in Raskin, V. (ed.), The Primer of Humour Research, Berlin \& New York: Mouton de Gruyter, pp. 361-398.

Laurenson, P., \& Collins, D. (2007). 'Beyond punitive regulation? New Zealand Local Governments' responses to homelessness'. Antipode 39 (4), pp. 649-667.

Lee, B. A., Farrell, C. R., \& Link, B. G. (2004). 'Revisiting the Contact Hypothesis: The case of public exposure to homelessness'. American Sociological Review 69 (1), pp. 40-63.

Miller, H. (1991). On the Fringe: The Dispossessed in America. Toronto: Lexington.

Mitchell, D. (1995). 'The end of public space? People's park, definitions of the public, and democracy'. Annals of the Association of American Geographers 85 (1), pp. 108-133.

Mitchell, D. (1998). 'Anti-homeless laws and public space: Begging and the First Amendment'. Urban Geography 19 (1), pp. 6-11.

Netdoctor (CTscan). (2013). URL: http://www.netdoctor.co.uk/health_advice/examinations/ctgeneral.htm [Accessed 15 March 2013].

Nicholls, C. M. (2009). 'Agency, transgression and the causation of homelessness: A contextualised rational action analysis'. European Journal of Housing Policy 9 (1), pp. 69-84.

O'Brien, M., \& de Haan, I. (2002). 'Empowerment research with a vulnerable group homelessness and the social services: The story of a research project'. Social Work Review 14 (1), pp. 29-35.

Parsell, C. (2011). 'Homeless identities: enacted and ascribed'. The British Journal of Sociology 62 (3), pp. 442-461.

Pascale, C. (2005). 'There's no place like home: The discursive creation of homelessness'. Cultural Studies $\leftrightarrow$ Critical Methodologies 5 (2), pp. 250-268.

Phelan, J., Link, B. G., Moore, R. E., \& Stueve, A. (1997). 'The stigma of homelessness: The impact of the label "homeless" on attitudes toward poor persons'. Social Psychology Quarterly 60 (4), pp. 323-337.

Pogrebin, M. R., \& Poole, E. D. (1988). 'Humor in the briefing room: A study of the strategic uses of humour among police'. Journal of Contemporary Ethnography 17 (2), pp. 183210.

Radley, A., Hodgetts, D., \& Cullen, A. (2005). 'Visualising homelessness: A study in photography and estrangement'. Journal of Community \& Applied Social Psychology 15 (4), pp. 273-295.

Ritchie, L. D. (2011). “'You're lying to Jesus!": Humour and play in a discussion about homelessness'. Humour: International Journal of Humour Research 24 (4), p. 481.

Sacks, H. (1989). 'Lecture Four: An impromptu survey of the literature'. Human Studies 12 (3/4), pp. 253-259.

Sacks, H. (1992). Lectures on Conversation, Vol. 1. Oxford: Blackwell Publishing.

Sanders, T. (2004). 'Controllable laughter: Managing sex work through humour'. Sociology 38 (2), pp. 273-291.

Silverman, D. (1993). Interpreting Qualitative Data. London: Sage.

Terry, C. M. (1997). 'The function of humour for prison inmates'. Journal of Contemporary Criminal Justice 13 (1), pp. 23-40.

Tratt, D. (2005). 'Blanket politics'. Capital Times, 1 December. URL: http://www.capitaltimes.co.nz/article/465/Blanketpolitics.html. 
Ungar, S. (1984). 'Self-mockery: An alternative form of self-presentation'. Symbolic Interaction 7 (1), pp. 121-133.

Urban Tarzan. (2007). The Eastern Press, October 12, pp. 2-8.

Wilkinson, A. (1983). 'On the Skids: The management of respectability on skid row', in Hill, M.S., Bowman, R. \& Carr-Gregg, C. (eds.), Shades of Deviance, Palmerston North, NZ: Dunmore Press, pp. 14-25.

Wellington City Council. (2004). Homelessness Strategy. URL: http://www.wellington.govt.nz.

Wong, S. (2010). 'Blanket Man mystery solved'. Marlborough Express, 4 June.

Wright, E., \& King-Jones, A. (Directors). (2003). Te Whanau O Aotearoa-Caretakers of the Land [Film documentary]. URL: http://www.nzonscreen.com. 